\title{
I samme båt
}

Tre generasjoner leger. De har alle vært i tvil om yrkesvalget. Men Herrens veier er uransakelige. Nå deler de frykten for spørsmålet «Er det en lege om bord?» og den lattermilde oppgittheten over folk som vil ha en gratiskonsultasjon i hyggelig lag.

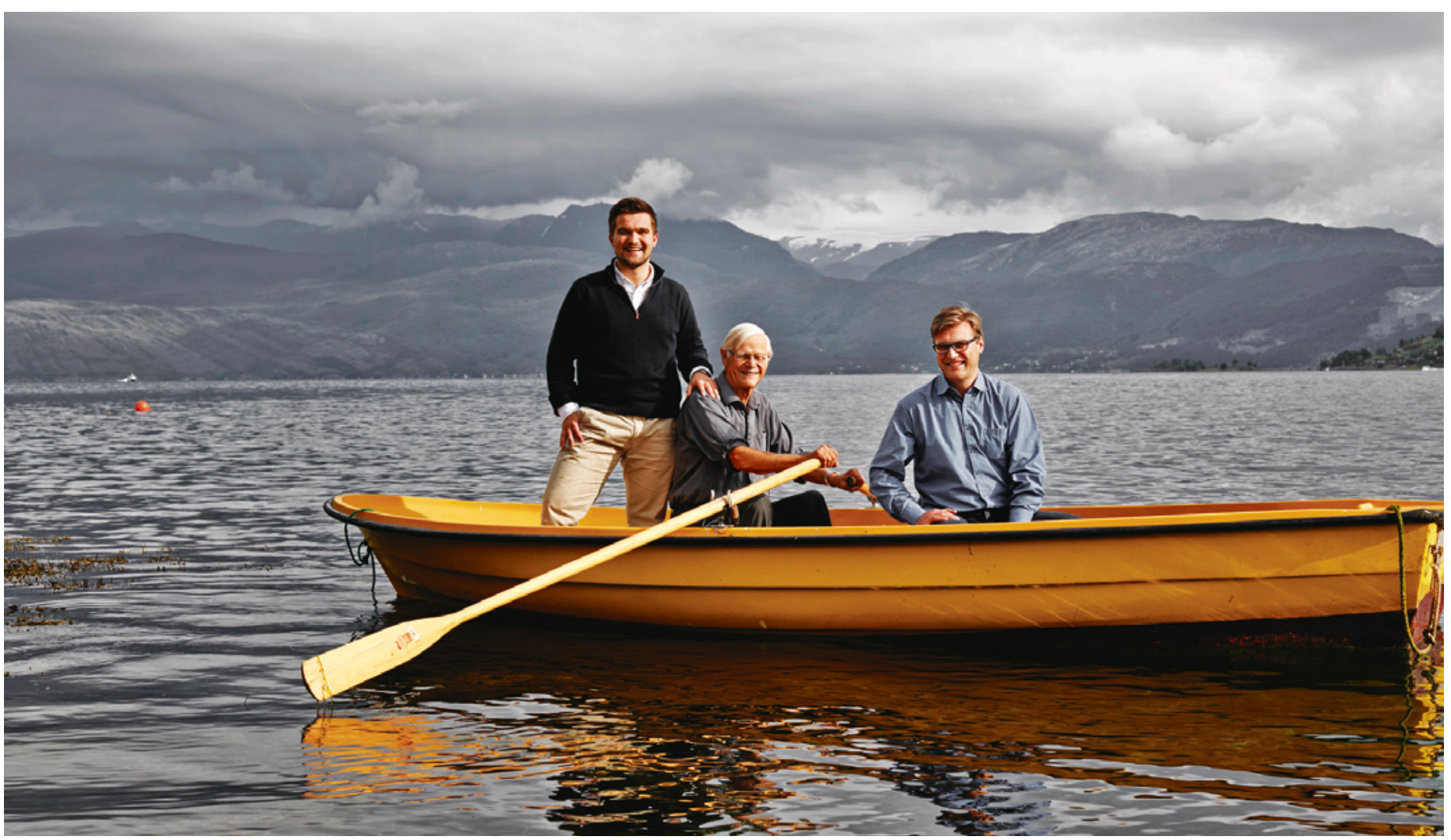

Eivind (t.v), Audun og Torgeir Storaas i samme båt. Foto: Ole Walter Jacobsen

Vi møter Audun Storaas i Norheimsund kyrkje. Han vil gjerne vise oss altertavlen han har laget. Et imponerende kunstverk $\mathrm{i}$ betong, stein, marmor og jern. 92 år gamle Audun er glad i å jobbe med stein. Kanskje fordi det er så mye av det der han bor, i postkortvakre Norheimsund i Hardanger. Han har lagt hver stein i forblendingsmuren rundt huset sitt også, et arkitekttegnet hus som glir nesten usynlig inn i landskapet ned mot fjorden. Fra sofaen ser han rett på Folgefonna. Hvit isbre, blank fjord, gul robåt, hjemmelaget eplekake. Kaken er det kona Margit Ann som har laget, i anledning at tre generasjoner leger skal møtes hjemme hos farmor og farfar og fortelle Tidsskriftets lesere hvordan det er å være i samme båt. Audun (92), Torgeir (54) og Eivind (26) er alle leger. Mye har endret seg fra da farfar var ung, men de har mye til felles også. Inkludert tvilen om de skulle velge legeyrket.

\section{Tro og tvil}

- Jeg hadde egentlig tenkt å bli arkitekt. Men da jeg satt med papirene fra landsgymnaset fikk jeg det klart for meg at jeg skulle bli misjonær. Reise ut. Og siden jeg ikke er så flink til å snakke, ble det mer naturlig å velge medisin enn teologi, forteller Audun. Han har lagt bak seg et langt yrkesliv som distriktslege, lungelege på Haukeland og lege på landsbygda i Sør-Afrika under apartheid. Han er også kunstner og har blant annet hatt tre separatutstillinger.

- Jeg var i tvil om jeg skulle velge musikken, forteller sønnen Torgeir. Han har blant annet vært vikar i Bergen Filharmoniske Orkester, vært på turné med Arve Tellefsen i Russland og tatt et år på musikkhøgskolen etter preklinisk praksis. Fiolinen er fortsatt en trofast følgesvenn, men medisinen tok ham til slutt. Nå er han overlege ved Ørenese-halsavdelingen og Yrkesmedisinsk avdeling ved Haukeland universitetssykehus. I 2008 tok han doktorgraden på yrkesrelatert bakerrhinitt og -astma og han har vært en av forkjemperne for at allergologi skulle bli et eget kompetanseområde.

Torgeirs sønn Eivind gikk flere runder med seg selv før han valgte medisinstudiet. Nå har han fullført utdanningen sin i Polen og skal starte turnustjenesten ved Sykehuset i Vestfold. I Polen var han aktiv i studentorganisasjonen ANSA, blant annet som landsleder. Han tror opplevelser fra barndommen er årsaken til at han valgte legeyrket.

- Pappa og jeg var på postkontoret, da en dame falt om. Jeg var vel 10-11 år. Vi hadde det egentlig travelt, men jeg husker pappa slo helt om. Plutselig hadde han god tid. Han sørget for frie luftveier, sjekket puls, ba noen ringe ambulanse og organiserte det hele på en rolig og trygg måte. 
Det gjorde inntrykk å se, og jeg tror det satte i gang noen prosesser, sier Eivind.

\section{Fra halvgud til menigmann}

Også Torgeir så veldig opp til sin legefar og tror det påvirket ham til å velge yrke. Det gjør inntrykk på en liten pjokk når pappa tas imot som en helt hvor enn han går.

- Legerollen har forandret seg veldig. Far og kollegene var jo halvguder i sin tid. En gang vi spilte fotball, var det en som gikk i bakken. Han lå der og vrei seg. «Hei, doktorgutt! Nå må du komme her og hjelpe til!» ropte de voksne. Jeg var bare 12 år, men de forventet såpass av en legesønn. «Nei... Det går vel bra det der...,» sa jeg, for det gjorde det jo som regel. Men heldigvis tok de ham med til far, og guttungen hadde visst kravebeinsbrudd, forteller Torgeir.

Han ser mange fordeler ved at leger i dag er tatt ned fra pidestallen, men også noen ulemper. - Det er bra på den måten at vi må skjerpe oss. Men på fars tid godtok folk at de kunne bli syke, til og med dø. Nå kommer pasienten med en ferdig diagnose fra Google og forventer helbredelse. Og som lege kjenner man på presset om ikke å bli forsinket med en diagnose, sier Torgeir.

Sønnen Eivind er enig i ulempene, som kan få negative følger både for lege og pasient. - Hvis du ikke har noen respekt, så følger kanskje ikke pasienten dine anmodninger. De tar ikke ferdig antibiotikakuren, de bytter mellom leger, de ber om second opinion. Sånt tar unødvendig med tid og ressurser, sier Eivind.

\section{På liv og død i Sør-Afrika}

Over et halvt århundre skiller ferdig utdannet farfar fra ferdig utdannet barnebarn. Mye har skjedd siden 1950-årene - heldigvis.

Audun startet lungespesialistutdanningen på Lyster Sanatorium for tuberkuløse. Behandlingen var å puste inn fjelluft. Om vinteren lå pasientene på rad og rekke i kurhaller, i sprengkulde. Av og til kom det en lege fra Lærdal, og han utførte torakoplastikk - et inngrep der opptil åtte ribbein ble fjernet for å få lungene til å klappe sammen. - Mange ble faktisk bedre, men de ble skjeve for resten av livet og hadde en del senplager. Det var en brutal behandling, gjort i lokalanestesi. Det var forferdelig, minnes han.

Opplevelsene fra Sør-Afrika under apartheid har også satt spor. Båtturen dit tok tre uker. Oppholdet varte i seks år. Først to år ved et sykehus i Zululand (senere Zulustan), deretter to år i Ekombe og to år i Umpumulo. Sykehuset i Umpumulo var et falleferdig bygg av bølgeblikk. Alle de tre sykehusene var drevet av Det Norske Misjonsselskap og var kun for den svarte befolkningen. Zuluene bodde i stråhytter med jordgulv, og alle kom med kroppen full av arr etter knivstikk, fordi de først hadde oppsøkt den lokale medisinmannen.

- Det var mye å gjøre. Halvparten av pasientene hadde tuberkulose, det var mye infeksjonssykdommer, proteinmangel og brannskadede barn som hadde falt $i$ ildstedet i hytta. Og sårbehandling etter slåsskamper. Zuluene var glade i å slåss, særlig under bryllupsfester, minnes Audun.

Han sier jobben minnet mye om å være distriktslege i Norge, der man som eneste lege i mils omkrets må stole på egen dømmekraft og kompetanse. Han dro ofte ut med landroveren og hentet pasienter hjemme i stråhyttene, eller behandlet dem på stedet -

\section{«Legerollen har forandret seg veldig. Far og kollegene var jo halvguder i sin tid»}

i skyggen av et tre. På sykehuset hadde han operasjonsstue og røntgenapparat. Han reddet mange, men ble også hjelpeløst vitne til at syke barn ble hentet av foreldrene før de var ferdigbehandlet. Tradisjonen tilsa at hvis barnet skulle dø, så skulle det dø hjemme.

Lille Torgeir tok sine første steg i SørAfrika. Familien bodde der til han var fire år, og han fikk småsøsken der også.

- Ja, vi fikk ett barn på hvert sted, forteller Audun. - Vårt første barn, Gesine, var fire uker prematurt og trengte både surstoff og kuvøse. Men vi hadde ingen av delene. Vi følte oss fullstendig hjelpeløse og klarte ikke å redde babyen. Hun døde etter fire timer. Vi turte ikke å ta sjansen på en ny hjemmefødsel, så Torgeir ble født på et sykehus i Eshowe. Han var en gladgutt. Ryktet sier at han ble født med fele under haka, men det vet jeg ikke. Jeg var ikke der, jeg hadde ikke tid. Sønnen vår Ståle ble født i et blikkskur av et sykehus i Ekombe, mens Valborg ble født i Umpumulo. Ståle ble prest og misjonær i Blå Nil-dalen. Det var tøft. Da han kom hjem fikk han en depresjon, og han valgte å forlate livet i 2003. Jeg ser frem til å møte ham igjen i himmelen, sier Audun.

\section{Jobben først}

Torgeir husker lite fra Sør-Afrika, annet enn en humpete tur på lasteplanet på landrove- ren og at faren snekret et fly til ham og søsknene som de kunne gynge i på balkongen. Audun smiler, men blir fort alvorlig igjen.

- Uff, det minner meg om at jeg har hatt dårlig samvittighet for at jeg har vært for mye opptatt av yrket mitt i forhold til familien. Det har kona merket svært godt også, at jeg ikke har vært så nær dem som jeg burde, sier han.

- Det er interessant hvis du spør min sønn om det samme, skyter Torgeir inn. Han har også tenkt at han kanskje kunne vært mer til stede for barna i oppveksten deres.

- Mamma og pappa la veldig mye i feriene våre, så jeg har utrolig mange gode ferieminner, sier Eivind diplomatisk. - Og han tok oss opp hver morgen og var nesten alltid hjemme til middag. Men det ble kanskje ikke så mange fotballkamper... De andre fotballforeldrene sa «Du er legesønn du, ja. Du kan kjøre med oss,» humrer han. - Legeyrket er ikke så familievennlig?

- Nei, det er ikke det. Særlig når man er i et spesialiseringsløp. Og så er det ekstra legevakt, vakter på sykehus, kurs...

- Jeg har talt opp. Jeg har gått mellom 50 og 60 kurs, sier Audun.

- Ja, det er en evig etterutdanning. Det har ikke forandret seg så mye, sier Torgeir.

- Men du hadde nok flere timer enn hva som forventes av en ung spesialistlege i dag, mener sønnen Eivind. - Legeforeningen har jobbet opp en del rettigheter der. Nå er det 18-timersvakter.

- Og dere er mange flere enn vi var, sier Audun. Han minnes tiden som distriktslege i Samnanger. I en periode var han også distriktslege i nabokommunen Fusa, fordi de manglet lege der. Det var ingen vaktordning, så telefonen ringte til alle døgnets tider. Kona Margit Ann, som er utdannet førskolelærer, måtte ta telefonen og fungere som legevakt mens Audun var ute på oppdrag. Det ble mange heftige turer i allslags vær.

\section{Cowboytilstander}

- En vinter var Samnangerfjorden helt islagt. Jeg fikk telefon om en gutt som hadde hogd seg i kneet, og jeg fikk inntrykk av at det var alvorlig. Men hvordan skulle jeg komme meg over en tre kilometer bred islagt fjord? Løsningen ble skøyter. Jeg løp ned til handelsmannen, kjøpte meg et par skøyter og kom meg over fjorden. Uten kjepp, uten følge. Det var jo galskap, sier Audun og rister på hodet.

Men med sysaker i legekofferten gikk det fint med pasienten på den andre siden. Barnebarnet Eivind har lært mye av farfar om hvordan det er å stå helt alene. Ingen å konferere med, bare ens eget hode. 


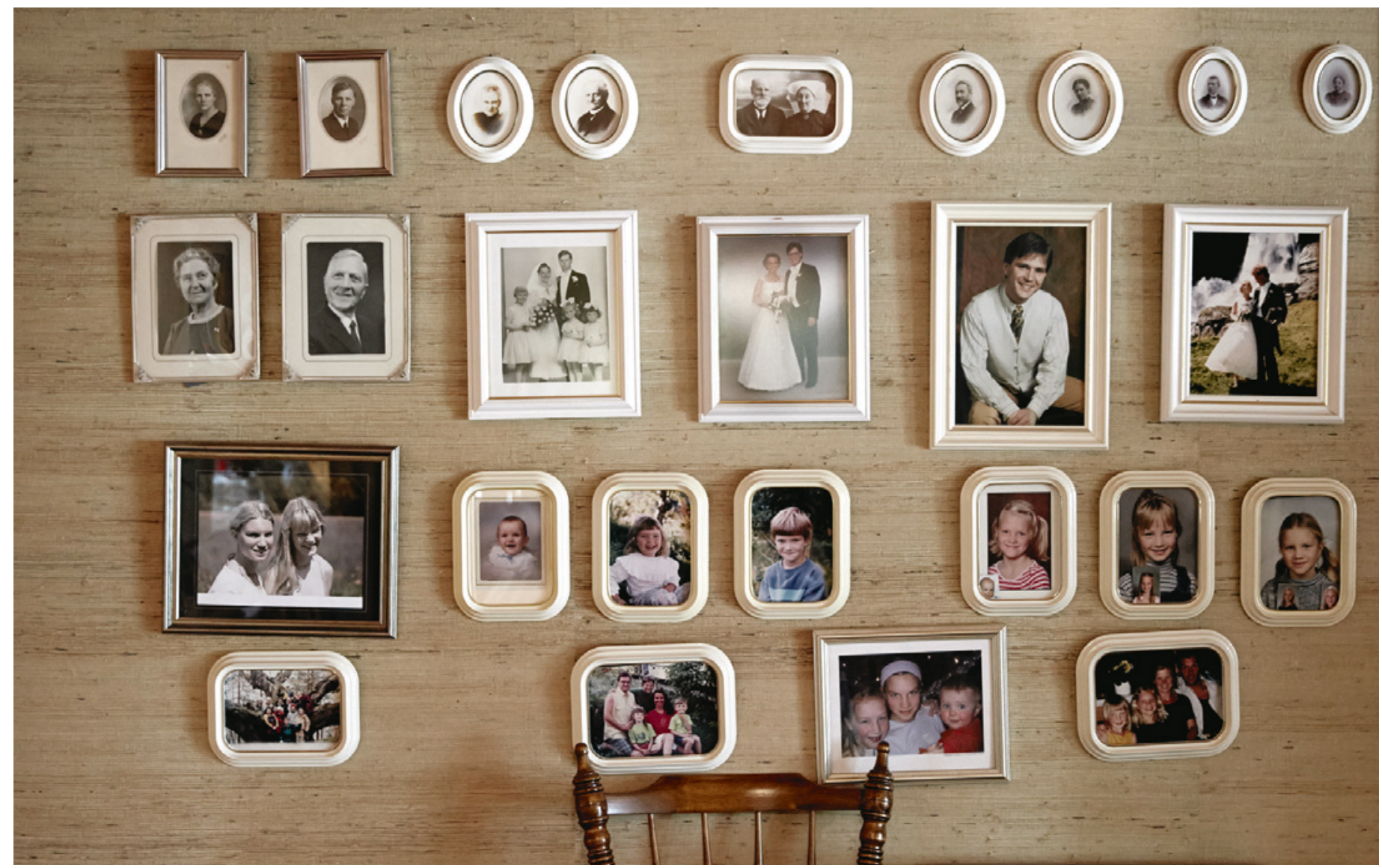

Mange generasjoner Storaas. Foto: Ole Walter Jacobsen

- Den akuttmedisinske tilgjengeligheten i distriktene har heldigvis forandret seg. Jeg synes det er spennende å høre hvor alene farfar faktisk var. Det høres cowboytøft ut. Men ansvarsbyrden er likevel noe av den samme. Følelsen av å stå helt alene, den har jeg også kjent på. Når sykepleieren sier til en pasient som er veldig syk at «Jeg har ringt til legen», og det går opp for meg at den legen er meg.. .Farfar har lært meg at jeg må trekke pusten og stole på meg selv. Ta et valg og stå for det. $\mathrm{Og}$ det funker jo! Eller du må ta et valg om å be om hjelp.

- Kjennes det som et nederlag å be om hjelp?

- Nei, nei, nei.

Eivind er sikker i sin sak. Farfar er ikke like sikker.

- Jeg følte meg dum, altså, hvis jeg måtte henvise til Haukeland en pasient med en litt usikker diagnose. En skal være litt selvsikker for å innrømme tvil. Men det var godt å kunne rådføre seg med kolleger på sykehuset, og senere da legebemanningen ble bedre, med andre leger i kommunen. Også den ferske turnuskandidaten kunne hjelpe med sin oppdaterte kunnskap, sier Audun.

De to er likevel enige om at det er bedre å legge inn en pasient for ofte enn for sjelden. Følgene er større hvis du feiler på det sistnevnte. - Hvis man legger inn for mange, blir folk sure på deg fordi du opptar ressurser. Men hvis du legger inn for få, kan du risikere ikke å få videre vikariat. Det verste er vel de legene som er selvsikre og ikke vet hva de ikke vet. Du må ha et bevisst forhold til din egen kunnskap, sier Eivind.

\section{To tomme hender}

Audun minnes tiden da to erfarne hender var tilnærmet det eneste man hadde å tilby. Han undersøkte pasientene med fingrene, tok på dem. Og hadde mye hjelp i stetoskopet.

- Før kunne vi perkutere ut en cyste i lungene. Var det krepitasjon ved auskultasjon? Var det fuktig eller tørr krepitasjon? Nå gjør man ikke sånn. Nå sender man pasienten på røntgen og CT og får fasitsvaret på bilder, humrer han.

Blodprøver og urinprøver var et kapittel for seg. - I gamledager smakte de på urinen for å finne ut om pasienten hadde sukkersyke.

- Har du gjort det, spør Tidsskriftets utskremte forferdet. Audun skoggler i sofaen så kaffekoppen skrangler på skålen. - Nei, nei, vi hadde strimler.
Legehumoren sitter løst. Eivinds morfar var også lege. Artur Voll var indremedisiner og kardiolog, og var i 20 år overlege ved medisinsk avdeling på Hamar sykehus. Mormor Martha var sykepleier. Det er blitt litt legeprat i familieselskapene. Men ikke plagsomt mye, kan farmor Margit Ann forsikre om.

- Nei, det har ikke vært til besvær, sier hun på fint bergensk, med trykk på ikke.

- Heller det motsatte. Og jeg har vært veldig stolt av dem. De har hjulpet mange mennesker, så vidt jeg vet.

- Kona sier at jeg har misunt barna mine, og det har hun visst rett i, skyter Audun inn. - Torgeir har vært så flink hele tiden, alle eksamener gikk som en lek og før vi visste ordet av det så hadde han tatt doktorgraden. Mens jeg sitter her som distriktslege, humrer han.

- Det har du ikke sagt før! Torgeir er lettere sjokkert over bekjennelsene i treseteren.

- Nei... Men det var jo et valg, så jeg har ingenting jeg skulle ha sagt, sier Audun tørt.

\section{Smerter, sanser, følelser}

Legeyrket er oppturer og nedturer. De tøffe opplevelsene brenner seg fast. Ikke nødven- 


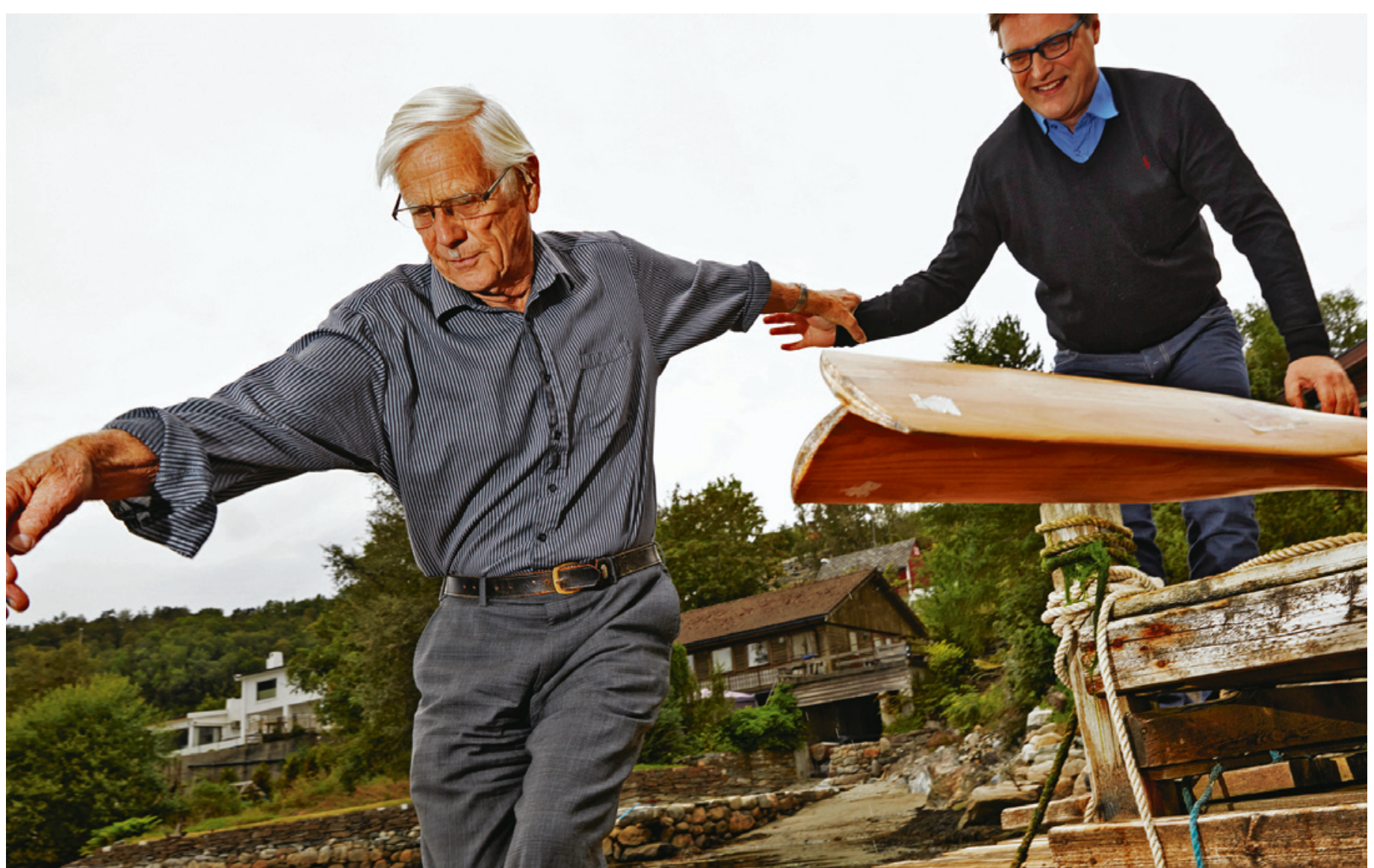

Med en hjelpende hånd fra sønnen er det ingen sak for Audun (92) å komme seg ned i robåten. Foto: Ole Walter Jacobsen

digvis liv og død, men smerter, sanser, følelser. Eivind husker en svært syk pasient som hadde gjennomgått en tung operasjon. Eivind fikk i oppdrag å evakuere et hematom på ryggen hans. Det skulle være lett å stikke inn en nål og tømme ut puss og blod, mente han. Men han bommet, og den ellers så robuste pasienten hadde tydelig vondt. Han ba om å få prøve en gang til, men bommet igjen. Det er tøft å være den ferske legen som påfører en allerede hardt prøvet pasient enda mer smerte.

- Av fine opplevelser er det å kunne gi en god diagnose til en kreftpasient. En nygift småbarnsfar som har enorme utbredelser av kreft i hele kroppen, og så vet man først ikke hvilken type det er. Hvis han har den ene typen, har han tre uker igjen å leve, hvis han har den andre, så blir han frisk. Og så sier overlegen: «Eivind, dette prøvesvaret skal du få lov å gi». Tenk å få gå inn og si at dette her skal gå helt fint!

Torgeir husker en pasient som hadde vært langt nede, men som var i ferd med å få et godt liv igjen, komme i sosialt gjenge, bli med i en vinklubb. - Jeg skulle operere ham i nesen, en helt ukomplisert operasjon. Så mistet han luktesansen. Det er en sjelden komplikasjon.
Det er nok noe av det verste jeg har opplevd som lege, sier Torgeir, og tilføyer:- Heldigvis er det ingen som har tapt sitt liv.

Hos Audun er det mange episoder som har satt varige spor. En fisker som hadde besvimt og som lå i bunnen av en sjakt i båten sin. Umulig å nå ned til. Fiskeren døde foran øynene hans. Og en bevisstløs pasient som måtte fraktes milevis i ambulanse, på smale, svingete vestlandsveier, med en bilsyk og svimmel Audun som fortvilet forsøkte gjenoppliving under hele kjøreturen. Vel fremme på sykehuset viste det seg at pasienten hadde kastet opp under turen, og ble kvalt av sitt eget oppkast. Da måtte kollegaen i mottaket trøste en gråtende og fortvilet distriktslege.

\section{Man tager hvad man haver}

- Av de beste minnene er da en gutt med hjertestans våknet til liv igjen etter at jeg traff med adrenalinsprøyten rett $\mathrm{i}$ hjertet. $\mathrm{Og}$ fra en norsk vinterdag da jeg ble oppringt om at en mann på andre siden av fjorden hadde falt $\mathrm{i}$ isvannet. Det hadde tatt de fortvilte pårørende lang tid å få ham opp av vannet. Vi fikk, med mye strev, fraktet ham opp til nærmeste hus og lagt ham på et bord, men der var det verken elektrisitet eller innlagt vann. Mannen hadde ikke puls eller hjertelyd og legekofferten var til liten hjelp. Jeg hadde lagt merke til at det lå en haug med takpanner på utsiden, så jeg fikk de pårørende til å legge disse på den vedfyrte komfyren. Etter hvert som takpannene ble varmet opp, la vi dem rundt på kroppen til den stivfrosne mannen. Plutselig åpnet han øynene! Han brukte litt tid på å komme seg igjen, men han levde i mange år etter dette.

Til tross for at 66 år skiller den ene fra den andre kan de be hverandre om råd og støtte. Ikke om elektrolyttverdier og diagnosekoder, men om hvordan man forholder seg til kolleger og pasienter. Hvordan man må stole på egen kunnskap. Det er godt å ha hverandre.

- Jeg føler jeg har ryggdekning, sier Eivind. - Hvis jeg er usikker på om jeg har gjort det rette, kan jeg fortelle pappa at jeg gjorde slik og sånn. Og så kan pappa svare at «jammen det hørtes jo fornuftig ut», eller «det vil tilfalle en annens ansvar, så neste gang kan du konferere med ham». Og min mor kan svare på spørsmål som går på kommunikasjon, for hun holder kurs i samhand- 
ling og kommunikasjon for helsevesenet. Jeg er veldig heldig der.

\section{Mye til felles}

De tre deler mer enn legeyrket: gudstroen, omtanken for andre og interessen for utviklingsarbeid. Torgeir deltar i et utviklingsprosjekt i Zanzibar i Øst-Afrika. Det er et samarbeidsprosjekt mellom flere avdelinger ved Haukeland universitetssykehus og Mnazi Mmoja Hospital. En vinn-vinn-situasjon for begge parter, ifølge Torgeir. Eivind har vært i Afrika to ganger, som hospitant ved et distriktssykehus i Etiopia, og på et «outreachprogram» i slummen vest i Kenya. Han har, i likhet med sin farfar, samlet inn penger til dem som trenger det mest. Mye av farfar Auduns kunstinntekter går til veldedige formål, blant annet via Kirkens Nødhjelp.

Far og farfar har begge vært militærleger, mens sønnesønnen tar fatt på den samme jobben etter turnustjenesten. Musikaliteten deler de også. Mens far spiller fiolin, akkompagnerer farfar på tverrfløyte og farmor på piano. Sønnesønnen foretrekker mer sportslige sysler, men drar frem gitaren i hyggelig lag og har ifølge pappa Torgeir en svært så god sangstemme. Og han innrømmer etter hvert at han har spilt noen år i buekorps.

\section{«Er det en lege om bord?»}

De tre deler også skrekken for at noen under en flytur skal rope «Er det en lege om bord?». To av dem har opplevd det, og håper det blir lenge til neste gang. Det er ikke mye av hjelpemidler der oppe.

- Førstehjelpsskrinene om bord i fly har ingenting i seg! Veldig lite i alle fall. En bandasje og noen paracet er alt. Ingenting som kan hjelpe deg! Adrenalin og nitroglyserin kunne du kjøpt deg litt tid med, og morfinpreparater burde også vært der, sier Eivind oppgitt.

Pappa Torgeir minner om misbruksfaren. - Men det kunne vel vært noe der som ikke kan misbrukes, mener Eivind.

Audun måtte hjelpe en dame med hovne bein. Han tok på henne støttestrømpene sine og ba henne oppsøke lege så snart hun landet. Torgeir måtte roe en dame med flyskrekk.

- Jeg satt i et overfylt charterfly og det tok litt tid før vi fikk ta av. En dame hadde kortet ned ventetiden med å helle innpå konjakk, og da vi skulle ta av, friket hun helt ut. Jeg sa at hun enten måtte forlate flyet eller sette seg rolig ned. Tror jeg ga henne noe beroligende. Men viktigst var at et av besetningsmedlemmene satt med henne hele veien frem, så det endte godt. På en måte. For da vi kom frem fikk jeg vite at hun bare måtte komme seg avgårde, for denne årlige sydenturen med

\section{«På fars tid godtok folk at de kunne bli syke, til og med dø. Nå kom- mer pasienten med en ferdig diagnose fra Google og forventer helbredelse»}

venninner var hennes eneste friperiode fra et vanskelig samliv med en voldelig mann. Kontrastene i livet er store, sier Torgeir.

\section{Svette føtter og syke tanter}

De innrømmer at det kan ha sine ulemper å være lege når man har fri og skal kose seg. Eivind har allerede opplevd flere ganger at folk vil ha konsultasjoner på fest. Han skratter mens han forteller om en i overkant frekk bekjent.

- Jeg var på grillfest hos venner da han plutselig plantet en kjempestor svett mannefot i fanget mitt og spurte «er denne tåneglen inngrodd?». Først undersøkte jeg ham pliktskyldigst, fersk som jeg var. Men så sa jeg bestemt at han fikk se å fjerne den foten fra mitt fang og heller kontakte fastlegen sin. Han har ikke beklaget engang, han mener det kommer med yrket mitt, sier Eivind liksomsjokkert.

Torgeir innrømmer at han som øre-nesehals-lege har fått mange telefoner fra familie og venner med små barn. Og enkelte tanter trenger råd mellom fyrstekaker og vestlandslefser. Det tar Torgeir med stor ro.

- Joda, noen skal ha litt ekstra, vet du.
- Jeg hadde det sånn før jeg pensjonerte meg, sier Audun. Men så sa jeg fra meg lisensen min slik at jeg ikke kunne skrive ut resepter lenger. Da sluttet de å ringe, humrer han.

\section{Trim for eldre}

92-åringen holder seg uforskammet godt. Mens Tidsskriftet er på besøk må han to ganger ut i robåten for å fotograferes. Været og lyset forandrer seg fort på Vestlandet, så fotografen må handle raskt. Veien fra huset og ned til brygga er bratt og trappen består av steinheller i ujevne formasjoner. Farfar tar det sporty. Hva er hemmeligheten? Morgengymnastikk. Hver eneste morgen i flere tiår har han gjort de samme bøy- og tøyøvelsene. Først alene ved sengekanten, og så sammen med kona ved frokostbordet.

- Skal vi demonstrere det, spør han ivrig. Kona er ikke med på sånne ablegøyer ved kaffebordet, men farfar reiser seg opp og viser armer i været og bein til siden og bak.

- Ti ganger sånn og ti ganger sånn. Det hjelper på balansen. Og så strekk opp der, tåhev og sakte ned, demonstrerer han.

Løpe har han også begynt med, for å bevise at det aldri er for sent å begynne å trene. Og for å holde diabetesen i sjakk. Torgeir er ikke like glad for at faren hans insisterer på å løpe med hendene i lomma i det ulendte terrenget.

- Men jeg skal si dere at han blir helt utslitt av å rekreere, skyter kona inn fra sidelinjen. - Han har bedre av å bevege seg. Han må jo forstå det selv, han er jo lege, slår hun tørt fast.

Latteren runger igjen. Stemningen er varm og god mellom de tre generasjonene som sitter ved siden av hverandre i sofaen. De setter tydelig pris på hverandres selskap. - Ja, vi er jo veldig glad i hverandre, sier Torgeir. Han får bekreftende nikk fra sønnen. Farfar ser lur ut.

- Jasså, er vi det?

\section{Eline Feiring}

eline.feiring@legeforeningen.no Tidsskriftet 